\title{
SOME ASPECTS OF THE ECONOMICS OF CATASTROPHE RISK INSURANCE
}

\author{
CHRISTIAN GOLLIER
}

CESIFO WORKING PAPER No. 1409

CATEgory 3: Social Protection

FEBRUARY 2005

An electronic version of the paper may be downloaded

- from the SSRN website:

wWw.SSRN.com

- from the CESifo website:

www.CESifo.de 


\title{
SOME ASPECTS OF THE ECONOMICS OF CATASTROPHE RISK INSURANCE
}

\begin{abstract}
The ability to share risk efficiently in the economy is essential to welfare and growth. However, the increased frequency of natural catastrophes over the last decade has raised once again questions associated to the limits of insurability in a free-market economy, and to the relevance of public interventions on risk-sharing markets. In this paper, we explore the potential reasons for the lack of insurance specifically associated to catastrophe environmental risks. Our final aim is to link each source of possible market inefficiency to its possible remedies.
\end{abstract}

JEL Code: D52.

Christian Gollier

University of Toulouse 1

Institute of Industrial Economics

Place Anatole France

31042 Toulouse cedex

France

gollier@cict.fr 


\section{Introduction}

The standard economic model of risk exchanges predicts that competition on insurance markets leads to a Pareto-efficient allocation of risks in the economy. In particular, it states that all diversifiable risks in the economy will be washed away through mutual risk-sharing arrangements. All risks will be pooled in financial and insurance markets. Moreover, the residual systematic risk in the economy will be borne by the agents who have a comparative advantage in risk management, as insurers and wealthy investors. In short, it means that all risks are insurable. This prediction is obviously contradicted by casual observations. Many diversifiable risks are still borne by individuals. Indeed, individual consumption levels are not perfectly correlated in the population, i.e., for every shock in the economy, they are "winners" and "losers". This is symptomatic of an inefficient risk sharing ex ante. To illustrate, it is believed that most of the supply of insurance coverage against terrorism risk would have disappeared without a public intervention in the United States after September 11, 2001. Also, there is ample evidence that only a limited fraction of homeowners purchase insurance coverage against earthquakes, floods and other natural damages in countries without strong public interventions. Finally, without a considerable internationalization of insurance and financial markets, we may expect that risks associated to climate changes will be favorable to some countries and detrimental to others.

The adverse consequences of the limits to insurability are generally overwhelmingly underestimated. The management of risks and the management of production cannot be disentangled without a efficient risk-sharing markets. It forces small entrepreneurs to bear the risk linked to their investment. It yields a reduction in investment, employment and growth. In addition, the inability of our economies to efficiently transfer risks affecting human capital forces households to bear a larger risk over their lifetime. Given risk aversion, it has a dramatic adverse effect on welfare.

The possibility to transfer a risk on the market place is contingent upon whether the buyer is ready to pay a larger price than the minimum price at which the seller is ready to sell. Consequently, the concept of a limit to insurability cannot be defined only on the distributional characteristics of the risk, but it should also take into account the economic environment. Berliner (1982) enumerates the criteria to define insurability. The actuarial view on

this problem is usually summarized by stating that a risk is insurable if the 
Law of Large Numbers is at work. It means that the maximum potential loss may not be infinite, or very large. Similarly, risks should not be too much positively correlated. In addition, it means that insurers should not accept risks with a too low probability of occurrence. Also, the risk must exist: a realized risk cannot be insured. The legal environment must be stable, or predictable. Finally, an objective distribution function can be estimated.

This definition is not entirely satisfactory. As said before, a transaction on the market is possible if the two parties are willing to transfer the underlying "good" against a specific price. This joint willingness can exist only if the seller and the buyer find it advantageous to exchange. We define a risk as being uninsurable if, given the economic environment, no mutually advantageous risk transfer can be exploited by the consumer and the suppliers of insurance. Partial uninsurability occurs when the parties can exploit only part of the mutually advantageous transfer of risk. Whether there exists a mutually advantageous risk exchange between the two parties is an interesting question that has been examined by several authors as Arrow (1965), Borch (1960), Raviv (1979) and Aase (1993). The basic model is a perfect competitive insurance market in which it clearly appears that indeed the Law of Large Numbers plays an important role to evaluate the social surplus of the transfer of risks. But, contrary to the standard actuarial view, the maximum potential loss and the probability of loss have an ambiguous effect on the size of the transfer of risk at equilibrium. In addition some factors as the degree of risk aversion of the agent, or her degree of optimism, are crucial in the insurability of risks in the economy.

The actuarial view on the limits of insurability appears to be too narrow. After all, the Lloyd's accepted to underwrite the risk of the capture of the monster of Loch Ness, and more standard insurance companies cover the risk of failure of Ariane V, the new European satellite launcher on which no data is available. Moreover, many risks on which the Law of Large Numbers could be used are beyond the limits of insurability. One cannot find insurers that would accept the risks of the absence of promotion, or of divorce.

The objective of this paper is to provide some insights on the recent developments on the economic analysis of the limits of insurability, specifically for catastrophic risks. There is no unified theory for it. Rather, there are a large set of economic reasonings explaining why some risks cannot be insured on the marketplace. All of them are related to a modification of one of the assumption in the Arrow-Borch standard model of perfect competition on 
insurance markets.

\section{The classical Arrow-Borch model of effi- cient risk sharing}

Economists ${ }^{1}$ have developed during the last thirty years a canonical model to deal with optimal insurance/risk-sharing and risk prevention. Our aim in this section is to review the assumptions and basic results of this simple model.

In the classical risk-sharing model, there is a large number of agents in the economy. Each agent has a risky endowment. Correlation among these risks is allowed. Agents are expected-utility maximizers, with an increasing and concave utility function. The following assumptions are made:

- There is no transaction cost.

- The distribution function of risks is common knowledge.

- The distribution function can depend upon prevention efforts by the agents. Efforts are observable at no cost.

- Losses are observable at no cost.

- There is full liability.

- The model is static, or there exists a complete set of insurance markets for future risks.

Under these conditions, we obtain the following well-known results:

- To each possible event affecting at least one agent, there will be a competitive market for claims contingent to that event. Agents will exchange bundles of state-contingent contracts that can be analyzed as an insurance contract. Competitive markets generate a Pareto-efficient allocation of risks in the economy in the sense that there exists no other feasible allocation of risks that would increase the expected utility of an

\footnotetext{
${ }^{1}$ See Borch (1962), Arrow (1953), Mossin (1968), Raviv (1978) and Gollier (1992).
} 
agent without reducing the expected utility of at least another agent. This allocation will satisfy the mutuality principle which states that everyone's final wealth depends only upon the aggregate wealth of the economy in the corresponding state. Namely, if there are two states of nature with the same aggregate wealth, the distribution of wealth among agents will be the same in the two states. This guarantees that all diversifiable risks are washed away. In particular, if there is no systematic risk in the economy, the aggregate wealth is certain, and by the mutuality principle, so will be the individual wealth levels. If a systematic risk exists, its sharing in the population satisfies a simple risk-sharing rule: the sensitivity of an individual's final wealth to the aggregate wealth in the economy is inversely proportional to its ArrowPratt degree of absolute risk aversion. In short, this means that more risk-averse agents should bear a larger share of the aggregate risk. Observe that this implies that all agents in the economy should participate to the bearing of the collective risk. ${ }^{2}$

- Despite risks depend upon efforts to prevent them, there is no moral hazard problem. Indeed, since efforts are observable, each party will condition the acceptance of the contract to strict requirement on risk prevention by the other party. Contractors will privately trade-off their cost of effort to the benefits of risk-sharing generated by the contract. For example, an insurer will provide a better premium rate to those entrepreneurs who accept to invest in fire sprinklers in their buildings. The competitive equilibrium yields a socially efficient level of risk prevention. To illustrate the idea, if there is no systematic risk, or if there is a risk-neutral agent in the economy, at equilibrium a 1 euro increase in prevention effort by any agent generates a 1 euro increase in expected aggregate wealth in the economy.

We conclude that in the classical problem of insurance and risk prevention, there is no need for public intervention. Risk are efficiently spread in the economy. This means in particular that agents are fully insured if risks are diversifiable. If they are not, the risk will be spread to the largest possible community. Also, agents get the good incentives to invest in a socially

\footnotetext{
${ }^{2}$ See Eeckhoudt and Gollier (1995) for a synthesis on Pareto-efficient and competitive risk-sharings.
} 
efficient level of risk prevention. These results do not fit with the real world. Insurance and reinsurance mechanisms are good in spreading standard risks in a very efficient way over a worldwide community of investors who get a return for the portfolio risk they take. This is the case for automobile, fire and most liability risks for example. This is not the case for most natural risks. In the next sections, we review the reasons why the classical model fails to explain why these risks are hard to insure by the market. We also explore how private-public partnerships can improve efficiency.

\section{Transaction costs}

The prevalence of transaction costs in the insurance industry is a wellestablished fact. For many insurance lines like automobile insurance, transaction costs amount up to $30 \%$ of the premium. This is a striking difference with respect to financial markets, where transaction costs are generally not larger than 2 or $3 \%$. It is easy to understand why insurance markets are faced with much larger transaction costs: insurance contracts are tailored to individual risks, which are difficult to observe. Insurance companies must therefore develop expensive technologies to audit individual risks, both exante and ex-post. These costs are eventually passed on to the policyholder through a loading on the premium. On the contrary, financial contracts organize the sharing of standardized, aggregate risks that are easy to observe at low cost.

The existence of transaction costs is especially crucial in the case of catastrophic risks. Catastrophic risks are likely to trigger waves of claims from policyholders hit by the same event all at the same time. Auditing these simultaneous claims in a reasonable delay requires a large capacity of auditors. Because auditing technology is expected to exhibit decreasing returns to scale, the expected auditing cost per customers is likely to be larger for catastrophe risks relative to other insurance lines. In the same spirit, the limited auditing capacity will force insurance companies to randomize audits when faced to waves of claims. This is anticipated by opportunistic policyholders who can be tempted to exaggerate their losses when a catastrophe occurs. As a consequence, the problem of transaction costs on insurance markets is magnified in the case of catastrophic risks.

How do transaction costs affect the insurability of risks? There is no doubt 
that some individuals with a low degree of risk aversion will find these costs too expensive with respect to the benefit of the coverage. In fact, Mossin (1968) proved that it is never optimal to purchase full insurance when the premium contains a proportional loading. Thus, transaction costs is a source of partial uninsurability. More interestingly, Arrow (1965) showed that the optimal form of insurance contract is a contract with full insurance above a straight deductible if the loading only depends upon the actuarial value of the contract, i.e. the expected indemnity. Deductible insurance is a best compromise between the willingness to cover larger risk and the objective to limit transaction costs. The intuition is that the willingness to pay for coverage depends upon the variance of losses. When one reduces the size $t$ of the risk, the willingness to pay for insurance decreases as $t^{2}$, whereas deadweight transaction costs decrease as $t$. It implies that only large risks are insured. This is in contradiction with the observation that one has no problem to find insurance against cracks in one's windshield, but one cannot easily find insurance against much larger risks as earthquake insurance. We conclude that the existence of transaction costs is not a convincing explanation for insurance market failures for large risks.

The above argument holds specifically in the classical expected utility model. This model has been challenged for two decades by some economists and psychologists on the basis that it is only an approximation of households' attitudes toward risk. For example, Kahneman and Tversky (1979) performed experiments that tended to establish that people are much more affected by losses than by gains in wealth. That "loss aversion" should raise the demand for insurance, thereby making the transaction costs argument as a source of uninsurability even less credible.

The question is thus how to reduce transaction costs on catastrophe insurance markets. As explained above, transaction costs are large because the individual indemnity is a function of the individual loss, which is costly to observe. A standard response of the market is to impose a (partially disappearing) deductible, which implies that only policyholders with a loss larger than the deductible will submit a claim. As shown by Gollier (1987), this is a socially efficient solution when there is a fixed cost per claim. A solution is to relate the indemnity to something that is easier to observe. For example, an insurance strategy would be to offer contracts that are contingent only to an index of aggregate loss in the community to which the agent belongs. Of course, this raises the issue of the management of the basis risk by the pol- 
icyholders, but it yields the benefit generated by the low observability cost of the aggregate loss index. An extreme example of this strategy is provided by the development of "cat bond" markets during the last decade.

\section{Inefficient financial markets}

Financial markets are a natural place to organize the sharing of individual risks. In fact, insurers and reinsurers should be analyzed as financial intermediaries that "package" individual risks before transferring it to the market. The wave of securitization of individual risks observed during the last decade raises the question of why financial intermediation is necessary. In addition to the above-mentioned remark that markets may find it hard to monitor individual risks, it has long been documented that financial markets have been quite inefficient to spread risks to the largest possible community of economic agents. Two problems are particularly relevant for managing catastrophic risks: limited participation of individuals to financial markets and the international diversification puzzle. Both problems yield an inefficiently large risk premium in the insurance tariffs for catastrophic risks, yielding in turn an insurability problem.

The existence of various participation costs to financial markets implies that only the wealthier fraction of the population will invest in the stock market. Given that many people do not hold any stock portfolio, they do not hold shares of (re)insurance companies that are considering covering catastrophic risks. The remaining shareholders will require a larger risk premium to participate, because of the larger size of the risk. Since the risk premium increases as the square of the size of the risk, this can generate a sizeable effect on the risk premium, and in turn on the insurability problem.

Another argument is based on the international diversification puzzle, as stated by French and Poterba (991), and Baxter and Jermann (1997). They reported that US investors hold around $94 \%$ of their financial assets in the form of US securities. In Japan, the United Kingdom and Germany, the portfolio share of domestic assets exceeds $85 \%$ in each case. Whereas this effect is mitigated by the existence of international reinsurance treaties, it shows that catastrophic risks are not as much geographically disseminated as suggested by the theory. A possible explanation for the home bias of individual portfolios comes from various tax incentives for retirement funds to invest within 
the country. We believe that relaxing these investment constraints would alleviate the insurability problem for catastrophic risks by reducing the risk premium requested by shareholders of (re)insurance company to bear them.

We endorse the proposal of Robert Shiller (1993) to create new markets for claims on various indexes related to national incomes, or to these socalled new risks for which the current allocation is obviously inefficient. For example, an international mutualization of the risk of climate change would be very helpful, as we believe that most of it can be diversified away. Such an international risk-sharing can be attained either through a formal risksharing treaty among different countries, or through the creation of claims on regional indexes of damages generated by climate changes. Super-terrorism could be treated in a similar manner. A difficulty of the system comes from the moral hazard problem that large risk-sharing arrangements generate. Another difficulty, which is specific to the international treaty system, is due to the long-term commitment that such sharing device requires.

\section{$5 \quad$ Asymmetric information}

Since the seminal paper by Rothschild and Stiglitz (1976), it is recognized that the fact that insurers face an heterogeneous population of consumers is a source of inefficiency on insurance markets. Suppose that individual risks are heterogeneous in the population, and the observable characteristic of the agents are not perfectly correlated to the intensity of their risk. The adverse selection problem originates from the observation that if insurance companies calculate the premium rate on the basis of the average probability distribution in the population, the less risky agents will purchase less insurance than riskier agents. In the extreme case, the low-risk agent will find the premium rate too large with respect to their actual probability of loss. They will prefer not to insure their risk. Insurers will anticipate this reaction, and they will increase the premium rate to break even only on the population of high-risk policyholders. The presence of high-risk agents generates a negative externality to lower-risk agents who are unable to find an insurance premium at an acceptable premium rate. The policy recommendation that is relevant to reduce adverse selection is to make public all relevant information about risks. For example, insurers should be allowed to know whether the potential policyholder is highly exposed to some environmental risk. 
However, allowing insurance companies to discriminate price according to their information about the risk exposure of their customers raises an ethical issue. Suppose that the riskier group of agents is on average poorer than the less exposed group. Price discrimination on the insurance market would raise the premium rate for poorer consumers. Beside the redistributional issue, this may yield a solvency problem of the insurance demand. These two problems can be solved by imposing a no-discrimination rule to insurance companies (Rochet (1991)). In order to eliminate the adverse selection problem that this policy recommendation yields, it is necessary to combine the no-discrimination rule with making insurance coverage mandatory. This is what is done for example in France in the case of insurance of natural catastrophes. Given the difficulties to regulate insurance markets in this way, one should think of the alternative policy that would consist in redistributing wealth among low-risk and high-risk customers through a simple tax scheme.

The population of risks can be heterogeneous not only because agents bear intrinsically different risks, but also because they do not invest the same amount of their energy, wealth, or time to risk prevention. In particular, it has long been recognized that individuals that are better covered by insurance invest less in risk prevention if the link between the premium rate and the size of these investments is weak. It will be the case if insurers are not in a position to observe the investment in risk prevention by the insuree. In that case, the premium rate is not sensitive to the effort made by the policyholder to prevent losses. Obviously, contrary to the result of the classical model, there will be an inverse relationship between risk prevention and insurance coverage. The level of risk prevention will be inefficient. This is moral hazard. Anticipating this low degree of prevention and the higher frequency of losses that it entails, insurers will raise their premium rate, inducing policyholders to reduce their coverage. At the limit, no insurance can be an (inefficient) equilibrium. The moral hazard problem is particularly crucial when policyholders have a large control of their risk. To illustrate, this is why it is not possible to insure against many environmental and technological risks.

The policy recommendation to fight against ex ante moral hazard is the enforcement of norms for risk prevention. This is the case for environmental risks in which ships transporting chemical products have to satisfy several safety requirements that are imposed by regulatory agencies. Automobile driving norms are also standard, as speed limits, alcohol-free driving,.... Why 
these norms are mostly organized by a regulatory agency rather than by insurers is not completely clear. One reason is due to the combination of negative externalities and limited liability. If they are more than one principal supervising the implementation of norms, the information among the different principals should be pooled to save on monitoring costs. Heal and Kunreuther (2003) argue that a centralized prevention system can be useful to solve the "tragedy of commons" coming from the fact that each agent's effort yields an externality on the other policyholders' risk.

Another policy recommendation is to allow insurers to discriminate prices among different policyholders. Allowing for discrimination is a way to provide incentive to policyholders to invest in risk-reducing activities. In France again, insurers are not allowed to discriminate premium rate for natural risks. The consequence are by now obvious: many households built their house in areas that were secularly known to be flooded periodically. The absence of actuarial insurance pricing was supposed to be counterbalanced by the imposition of strict norms for where to build houses. But these norms have never been written.

\section{Limited liability}

Firms generate environmental risks that are borne by third parties. This raises the question of who should bear the burden of the risk. In most countries, firms found liable to a damage to others must indemnify them accordingly. This is done to force firms to internalize all costs generated by their choice. But indemnification is possible only up to the firm's financial capacity. Limited liability is a way to protect risk-takers against an excessive financial distress. But it has long been recognized that limited liability distorts the decision of the risk-taker in a way that is socially inefficient. This is because the limited liability gives firms the equivalent of a free put option. Put it in simpler terms, under limited liability, an insolvent firm can only benefit from taking more risk, because it does not bear the burden of losses. Therefore, if it is risk-neutral, it will seek to maximize the expectation of a convex function of its equity. As a result, it will systematically exhibit a risk-loving behavior, and adopt a very risky attitude that can be labelled "bet for resurrection". This is a kind of moral hazard problem. Risk aversion mitigates this result, but only for agents who are well capitalized, as shown 
by Koehl, Gollier and Rochet (1997). To sum up, it is likely that insurance markets for environmental liability risks will not work efficiently, even when risks are efficiently priced by insurance companies. Another way of looking at this problem is that the insurance contract creates a "deep pocket" where victims can find compensation for their losses.

Limited liability thus raises several important questions. How to organize compensation for those who bear the negative environmental externalities? How to build an incentive-compatible mechanism that increases loss prevention by firms? How to force firms not to under-capitalize their subsidiaries which are in charge of managing the riskiest part of the business? Two routes have been used. The first one is compulsory insurance. This solves the misallocation of risk in the economy and the organization of a system to compensate the victims. But, most of the time, compulsory insurance has been funded by a flat, non-discriminatory, non-incentive-compatible insurance tariff. The policyholder's investment in loss prevention is not observed by the fund, either because it is difficult to get information on it, or because the fund did not get the good incentive to organize an incentive-compatible system.

The second route has been to organize "deep pocket" for decision makers. Under the US CERCLA, when a bank has been closely involved in the monitoring of a firm's activities, it may be considered as liable for cleaning up the environmental damages generated by the insolvent firm. The objective of this strategy is to force risk-takers to internalize the full cost of potential losses: banks will increase the loan rate of riskier firms, and they will have the good incentive to monitor their environmental risks. However, as observed by Boyer and Laffont (1995), there is no reason to believe that the insurer can monitor the firm at no cost. As a consequence, the CERCLA legislation introduces more asymmetric information on credit markets. There will be more credit rationing, the cost of capital will be larger, and the structure of banking contracts for firms will be affected. Is insurability worth this cost?

The existence of extensive bankruptcy costs on financial markets implies that catastrophe risks cannot be insured without the government paying the role of reinsurer of last resort. This is a key element in the success of both the terrorism risk insurance (TRIA) program in the United States, and the insurance of natural catastrophes in France for example. It is noteworthy that this public intervention to the allocation of risk in the economy is viable only if it is clearly defined ex-ante. This is a prerequisite for the efficient 
functioning of the (re)insurance markets.

\section{$7 \quad$ Lack of predictability}

There are many instances in which the random variable describing the risk has no objective probability distribution. This can be due to the absence of historical data. Or because of our imperfect scientific knowledge, for those who believe in a deterministic world. To illustrate, who knows the actual probability distribution of a major leak in some specific type of nuclear plan, the probability of transmission to the human being of the so-called "mad cow" disease, the probability of failure of the new European satellite launcher Ariane $\mathrm{V}$, or the probability of the average temperature of the earth increasing by more than 3 degrees Celsius over the next century? The lack of predictability can also be due to a volatile environment, as is the case for future liability rules of the environmental policy in many countries. The ambiguity about the probability distribution raises several questions. Is it sufficient to explain the insurability problem typically associated to ambiguous risks? How to calculate a fair insurance premium? How to evaluate the benefits of an insurance contract for the insuree? What would be an efficient allocation of risks in the economy?

Cabantous (2003) examined this question through the following experiments. Seventy-eight french underwriters were asked to price two different risks. Risk 1 yields a loss $L$ with an unambiguous probability $p=0.2 \%$. Risk 2 yields the same loss in case of accident, but we don't know the true probability of an accident. It can be either $p_{\min }=0.1 \%$ or $p_{\max }=0.3 \%$ with equal probability. Thus, without any additional information, the prior probability of accident is the same for the two risks, i.e., they have the same unconditional actuarial value. In spite of this obvious fact, the french underwriters priced risk 2 at a much larger rate than risk 1 . More precisely, risk 1 was priced with a loading factor of $35 \%$ on average, whereas risk 2 had a loading factor more than doubled at $78 \%$ of the actuarial value. Underwriters seems to behave as if they would put a very large subjective probability of the worse scenario $p=p_{\max }$, which is typical of what economists use to refer to "ambiguity aversion". The concept of ambiguity aversion has received a precise theoretical content by the works of Gilboa and Schmeidler (1989). This large premium rate generated by the insurers' ambiguity aversion can 
potentially explain why the demand for insurance for ambiguous risks is so small at that price.

Notice that if both the policyholder and the insurer have the same degree of ambiguity aversion, they should use the same $p$ to compute expected utility on one side, and the actuarial value of the policy on the other side. This should not introduce any specific insurability problem. The ambiguity raises the premium required by the insurer to accept to cover the risk, but it also raises the policyholder's willingness to pay for insurance. An insurability problem may occur only if insurers are systematically more ambiguity-averse than consumers. Kunreuther, Hogarth and Meszaros (1993) conducted a series of studies to determine the degree of ambiguity aversion of insurers. They showed that many of them may exhibit quite a large degree of such an aversion. For which reasons this is the case remains an open question. This could for example come from an incentive problem. Underwriters are usually much more penalized when it happens ex-post that they "underestimated" the risk of loss than when they "overestimated" it. Underestimation leads to the much visible problem for the company to face a loss ratio much larger than unity (asbestos in the US, transfused blood scandal in France,...). Overestimation yields unearned potential profits that are usually not even mentioned by the principal. Thus, underwriters would not be "genetically" more ambiguity-averse. Rather, they react to biased incentives. Solving this uninsurability problem requires a modification of incentive schemes for underwriters.

\section{Dynamic aspects of insurability}

\subsection{Implicit risk-sharing versus insurance}

A substitute for market insurance is to organize an implicit or explicit system of solidarity for the unlucky citizens through an indemnity financed by the taxpayers. Social security is the most obvious example. The decision of the US government to compensate the relatives of the victims of September 11 and the shareholders of airline companies is another example. France is the prefect example of a country that established an implicit system of solidarity for unlucky citizens. Farmers and truck drivers for example can rely on the state to get compensations for adverse shocks to their profits. Victims of 
floods may expect to get indemnities that depend upon the power of their local representatives at the Parliament.

The solidarity system yields problems that are similar to those of the market insurance: adverse selection, moral hazard and fraud. Moreover, if the system is implicit, it generates some uncertainty about the level of the indemnity, because of the political nature of the intervention. But the most important difficulty is related to the non-stability of the coexistence of the solidarity system. If citizens believe that the state will compensate them for their damages, they will prefer not to insure the risk. Ex-post, the absence of insurance coverage forces the state to intervene. This is a case of self-fulfilling prophecy. One can mitigate this problem by asking the state to specify explicitly the conditions and the limits of national solidarity. However, such a commitment may be difficult. Ex-post, the social pressure for the public indemnification of the uninsured victims of a much publicized catastrophe will be strong. Solidarity kills market insurance. This problem can also be mitigated by offering public indemnities that are not contingent to the existence of an insurance contract covering the victim's loss.

An essential aspect of the policy issue here is thus the ability of the State to commit itself on an ex-post treatment of the victims of natural catastrophes. This commitment can be organized through a specific law organizing solidarity mechanisms under specific rules, as done for example by the United States through the passage of the Terrorism Risk Insurance Act of 2002. Delegating the management of the solidarity scheme to an independent institution is an alternative strategy to this commitment problem.

\subsection{Realized risk}

Individual risks exhibit serial correlations through time. For example, a site that already experienced many tornadoes is likely to be exposed to other tornadoes in the future. If allowed to do that, competitive insurers will certainly use these historical data to price these individual risks. The extreme form of this is a "realized risk" in which the evolution of the random variable in the future became deterministic, given the current situation. Obviously, there exists no mutually advantageous risk transfer in this case. In short, one cannot insure a risk ex-post.

The same kind of problem arises from other sources of information. For example, the improvement of our ability to forecast future earthquakes or 
terrorist attacks inflicts high stress to the sustainable long-term relationship between insurers and policyholders. An international climatic risk-sharing arrangement could be organized only as long as our scientific knowledge is insufficient to predict which countries will benefit from the climate change, and which ones will have to bear most of the damages. Hirshleifer (1971) already noticed that more information can have a negative value for Society. Early information on risks will make these risks uninsurable. This so-called "Hirshleifer effect" may be escaped if insurance could be organized prior to the revelation of the information.

This phenomenon indicates the importance for insurance markets to establish long-term relationships between the buyer and the seller of a risk. Insurance for environmental risks would have a much smaller value if, at any time, one party could renege the contract contingent to new information about the risk exposure of the policyholder. This links this discussion to the assumption made in the classical model that there exist insurance markets for future risks.

\subsection{Time diversification and catastrophe loan programs}

Risks can be transferred between individuals, but it can also be transferred through time via the credit markets. Economic agents can forearm themselves in the face of uncertainty by building financial reserves. In the face of random shocks on their future revenues, they can reduce the volatility of their consumption by reducing their reserves in case of an adverse shocks, and by increasing their reserves in the absence of catastrophes. This buffer stocks strategy has been examined by Yaari (1976), Deaton (1991) and Gollier (1994) for consumers in a life-cycle model. Yaari (1976) showed that an agent with an infinite time horizon and with risks that are independent through time would "time-diversify" his risks by an efficient borrowinglending strategy that perfectly smooths his consumption through time. No costly insurance would be necessary in this case.

Contrary to this theory, the "time-diversification" strategy is actually not a perfect substitute to insurance because agents have a finite lifetime, and because consumers face borrowing constraints. In particular, they cannot borrow in case of an "early hit" of damages that dries up their initial financial reserve. This is particularly a problem for catastrophe risks in spite of the low probability of occurrence, since the buffer stock to build to fore- 
arm oneself against the consequences of the damage is necessarily huge. A standard governmental policy in situations where a large population hit by a catastrophe faces a borrowing constraint is to provide subsidized governmental loans. Gollier (2003) considers a standard lifecycle model that can be used to measure the benefit of relaxing individual borrowing constraints. We have shown that the marginal benefit of governmental loan programs is marginal when an efficient insurance market exists, but easing borrowing constraints when risks are difficult to insure may have a large effect on welfare.

This analysis can be reinterpreted for insurance companies determining their strategies of capital accumulation and reinsurance. A starting insurance company has a low capacity to retain risks. It is thus forced to reinsure a large part of its business. If it is not caught by an "early hit" of catastrophic indemnities, its capacity to retain risk will grow. This will increase the capacity of the market. The ability of insurance companies to transfer wealth through time is thus central for organizing time diversification of catastrophic risks. But the modern theory of corporate finance indicates that managers in firms with a large financial reserve will be less efficient than managers in less capitalized firms where their job is at stake. Managerial inefficiencies open the door to raiders who could use the cash reserve of the insurance company for his own purpose. The bottom line is that it can be hard for insurance companies to accumulate financial reserves. This has an adverse effect on the capacity of the insurance market.

When catastrophic risks are difficult to insure, time diversification may provide a good substitute. Because consumers and insurance companies may face difficulties to smooth shocks through buffer stocks and borrowing, the state may be in a better situation to organize time diversification. The state has the credit worthiness and the long time horizon that are necessary to implement time diversification efficiently. As explained before, the best way to do this is likely to ask the state government to play the role of reinsurer of last resort, a backstop, by offering reinsurance contracts with a deductible corresponding to the capacity of the insurance market. The moral hazard problem that it generates should be mitigated by the usual methods (experience rating, norms of prevention,...). A frequent reassessment of the market conditions should be performed in order to leave maximum freedom to the market capacity. 


\section{Conclusion}

Insurance plays a key role in the functioning of our modern economies. Insurance contracts transfer individual risks to financial markets through shareholders of insurance companies. It allows for a reduction of risks borne by Society through diversification. It also allows for transferring risks to agents that have a comparative advantage to bear risks, i.e. more risk-tolerant agents. The added value for the economy is considerable: it directly increases the welfare of the risk-averse policyholders, but it also induce risk-averse entrepreneurs to invest more in risky activities, thereby increasing growth and employment.

This view on the functioning of our economies is idealistic. There are several reasons for why a large proportion of uncertain events cannot be insured efficiently by competitive insurance markets, particularly those related to natural catastrophes. In this paper, we surveyed some of them, and in particular the inability to smooth catastrophic shocks over time due to solvency issues and liquidity constraints, the absence of objective probabilities, the large transaction costs of auditing large waves of claims simultaneously, and the Samaritan syndrome. We also discussed various strategies to remedy the economic efficiencies that are generated by this insurability problem. The optimal public-private partnership is obtained by combining the advantages of the two systems. Private insurers and reinsurers are good at selecting, pricing and monitoring individual risks and at auditing claims. They can efficiently transfer a first layer of these risks to financial markets. But they are not good at retaining the upper layer of aggregate risks, given the solvency constraints that prohibit them to smooth shocks over time. The State can efficiently do that by using its ability to tax citizens both before and after catastrophes occur, thereby time-diversifying catastrophic risks. This is why it should play the role of reinsurer of last resort. A key element to the success of this public intervention is that the rules defining the conditions of the public reinsurance be completely explicit. This is only in this way that we will put to a minimum the inefficiencies inherent to any public regulation, in particular those related to the crowding out of private insurance by public solidarity. 


\section{References}

Aase, K. K., (1993), Equilibrium in a Reinsurance Syndicate: Existence, Uniqueness and Characterization, Astin Bulletin, 23, 185-211.

Arrow, K.J., (1953), Le Rôle des Valeurs Boursières pour la Répartition la Meilleure des Risques, Edition du CNRS, Paris.

Arrow, K.J., (1965), Aspects of the Theory of Risk Bearing, Yrjo Jahnsson Lectures, Helsinki. Reprinted in Essays in the Theory of Risk Bearing (1971), Chicago: Markham Publishing Co.

Baxter, M., and U.J. Jermann, (1997) The international diversification puzzle is worse than you think, American Economic Review, 87, 170-80.

Berliner, B., (1982), Limits of Insurability of Risks, Englewood Cliffs.

Borch, K., (1962), Equilibrium in a Reinsurance Market, Econometrica, 30, 424-444.

Boyer, M. and J.-J. Laffont, (1995), Environmental Risks and Bank Liability, mimeo, Université de Montéal.

Cabantous, L., (2003), Ambiguity and conflict aversion in the field of insurance: Insurers' attitude towards to imprecise probabilities, unpublished manuscript, University of Toulouse.

Deaton, A., (1991), Saving and Liquidity Constraints, Econometrica, 59, 1221-1248.

Eeckhoudt, L. and C. Gollier, (1995), Risk: Evaluation, Management and Sharing, Harvester Wheatsheaf, Hertfordshire (G.-B.).

Eeckhoudt, L. and C. Gollier, (1999), The Insurance of Low Probability Events, Journal of Risk and Insurance, 66, 17-28.

French, K., and J. Poterba, (1991), International diversification and international equity markets, American Economic Review, 81, 222-26. 
Gollier, C., (1987), Pareto-Optimal Risk Sharing with Fixed Costs per Claim, Scandinavian Actuarial Journal, 62-73.

Gollier, C., (1992), Economic Theory of Risk Exchanges: A Review, in Contributions to Insurance Economics, G. Dionne Editor, Kluwer Academic Press, 3-23.

Gollier, C., (1994), Insurance and Precautionary Saving in a Continuous-Time Model, Journal of Risk and Insurance, 61, 78-95.

Gollier, C., (2001), The economics of risk and time, MIT Press, Cambridge, MA.

Gollier, C., (2003), To insure or not to insure: An insurance puzzle, Geneva Papers on Risk and Insurance, 28, 5-24.

Gollier, C., P.-F. Koehl and J.-C. Rochet, (1997), Risk-Taking Behaviour with Expected Utility and Limited Liability: Applications to the Regulation of Financial Intermediaries, Journal of Risk and Insurance, 1997, 64, 347-370 .

Gilboa, I. and D. Schmeidler, (1989), Maximin expected utility with non-unique prior, Journal of Mathematical Economics, 18, 141, 153.

Heal, G., and H. Kunreuther, (2003), You only die once: Managing discrete interdependent risks, NBER working paper 9885, Cambridge, MA.

Hirshleifer, J., (1971), The Private and Social Value of Information and the Reward of Inventive Activity, American Economic Review, 61, 561-574.

Kahneman, D. and A. Tversky, (1979), Prospect theory: An analysis of decisions under risk, Econometrica, 47, 313-237.

Kunreuther, H., (1996), Mitigating Losses and Providing Protection Against Catastrophic Risks: The Role of Insurance and Other Policy Instruments, Geneva Papers on Risk and Insurance Theory, forthcoming.

Kunreuther, H., R. Hogarth, and J. Meszaros, (1993), Insurer ambiguity and market failure, Journal of Risk and Uncertainty, 
7, 71-87.

Mossin, J., (1968), Aspects of Rational Insurance Purchasing, Journal of Political Economy, 76, pp. 533-568.

Raviv, A., (1979), The Design of an Optimal Insurance Policy, American Economic Review, 69, pp. 84-96.

Rochet, J.-C., (1991), Incentives, Redistribution, and Social Insurance, Geneva Papers on Risk and Insurance Theory, 16, 143-165.

Rothschild, M. and J. Stiglitz, (1976), Equilibrium in Competitive Insurance Markets: An Essay on the Economics of Imperfect Information, Quarterly Journal of Economics, 80, 629649.

Shiller, R.J., (1993), Macro markets, Oxford University Press.

Yaari, M.E., (1976), A Law of Large Numbers in the Theory of Consumer's Choice under Uncertainty, Journal of Economic Theory, 12, 202-217. 


\title{
CESifo Working Paper Series
}

\author{
(for full list see www.cesifo.de)
}

1346 Wolfgang Eggert and Martin Kolmar, Contests with Size Effects, December 2004

1347 Stefan Napel and Mika Widgrén, The Inter-Institutional Distribution of Power in EU Codecision, December 2004

1348 Yin-Wong Cheung and Ulf G. Erlandsson, Exchange Rates and Markov Switching Dynamics, December 2004

1349 Hartmut Egger and Peter Egger, Outsourcing and Trade in a Spatial World, December 2004

1350 Paul Belleflamme and Pierre M. Picard, Piracy and Competition, December 2004

1351 Jon Strand, Public-Good Valuation and Intrafamily Allocation, December 2004

1352 Michael Berlemann, Marcus Dittrich and Gunther Markwardt, The Value of NonBinding Announcements in Public Goods Experiments: Some Theory and Experimental Evidence, December 2004

1353 Camille Cornand and Frank Heinemann, Optimal Degree of Public Information Dissemination, December 2004

1354 Matteo Governatori and Sylvester Eijffinger, Fiscal and Monetary Interaction: The Role of Asymmetries of the Stability and Growth Pact in EMU, December 2004

1355 Fred Ramb and Alfons J. Weichenrieder, Taxes and the Financial Structure of German Inward FDI, December 2004

1356 José Luis Moraga-González and Jean-Marie Viaene, Dumping in Developing and Transition Economies, December 2004

1357 Peter Friedrich, Anita Kaltschütz and Chang Woon Nam, Significance and Determination of Fees for Municipal Finance, December 2004

1358 M. Hashem Pesaran and Paolo Zaffaroni, Model Averaging and Value-at-Risk Based Evaluation of Large Multi Asset Volatility Models for Risk Management, December 2004

1359 Fwu-Ranq Chang, Optimal Growth and Impatience: A Phase Diagram Analysis, December 2004

1360 Elise S. Brezis and François Crouzet, The Role of Higher Education Institutions: Recruitment of Elites and Economic Growth, December 2004 
1361 B. Gabriela Mundaca and Jon Strand, A Risk Allocation Approach to Optimal Exchange Rate Policy, December 2004

1362 Christa Hainz, Quality of Institutions, Credit Markets and Bankruptcy, December 2004

1363 Jerome L. Stein, Optimal Debt and Equilibrium Exchange Rates in a Stochastic Environment: an Overview, December 2004

1364 Frank Heinemann, Rosemarie Nagel and Peter Ockenfels, Measuring Strategic Uncertainty in Coordination Games, December 2004

1365 José Luis Moraga-González and Jean-Marie Viaene, Anti-Dumping, Intra-Industry Trade and Quality Reversals, December 2004

1366 Harry Grubert, Tax Credits, Source Rules, Trade and Electronic Commerce: Behavioral Margins and the Design of International Tax Systems, December 2004

1367 Hans-Werner Sinn, EU Enlargement, Migration and the New Constitution, December 2004

1368 Josef Falkinger, Noncooperative Support of Public Norm Enforcement in Large Societies, December 2004

1369 Panu Poutvaara, Public Education in an Integrated Europe: Studying to Migrate and Teaching to Stay?, December 2004

1370 András Simonovits, Designing Benefit Rules for Flexible Retirement with or without Redistribution, December 2004

1371 Antonis Adam, Macroeconomic Effects of Social Security Privatization in a Small Unionized Economy, December 2004

1372 Andrew Hughes Hallett, Post-Thatcher Fiscal Strategies in the U.K.: An Interpretation, December 2004

1373 Hendrik Hakenes and Martin Peitz, Umbrella Branding and the Provision of Quality, December 2004

1374 Sascha O. Becker, Karolina Ekholm, Robert Jäckle and Marc-Andreas Mündler, Location Choice and Employment Decisions: A Comparison of German and Swedish Multinationals, January 2005

1375 Christian Gollier, The Consumption-Based Determinants of the Term Structure of Discount Rates, January 2005

1376 Giovanni Di Bartolomeo, Jacob Engwerda, Joseph Plasmans, Bas van Aarle and Tomasz Michalak, Macroeconomic Stabilization Policies in the EMU: Spillovers, Asymmetries, and Institutions, January 2005 
1377 Luis H. R. Alvarez and Erkki Koskela, Progressive Taxation and Irreversible Investment under Uncertainty, January 2005

1378 Theodore C. Bergstrom and John L. Hartman, Demographics and the Political Sustainability of Pay-as-you-go Social Security, January 2005

1379 Bruno S. Frey and Margit Osterloh, Yes, Managers Should Be Paid Like Bureaucrats, January 2005

1380 Oliver Hülsewig, Eric Mayer and Timo Wollmershäuser, Bank Loan Supply and Monetary Policy Transmission in Germany: An Assessment Based on Matching Impulse Responses, January 2005

1381 Alessandro Balestrino and Umberto Galmarini, On the Redistributive Properties of Presumptive Taxation, January 2005

1382 Christian Gollier, Optimal Illusions and Decisions under Risk, January 2005

1383 Daniel Mejía and Marc St-Pierre, Unequal Opportunities and Human Capital Formation, January 2005

1384 Luis H. R. Alvarez and Erkki Koskela, Optimal Harvesting under Resource Stock and Price Uncertainty, January 2005

1385 Ruslan Lukach, Peter M. Kort and Joseph Plasmans, Optimal R\&D Investment Strategies with Quantity Competition under the Threat of Superior Entry, January 2005

1386 Alfred Greiner, Uwe Koeller and Willi Semmler, Testing Sustainability of German Fiscal Policy. Evidence for the Period 1960 - 2003, January 2005

1387 Gebhard Kirchgässner and Tobias Schulz, Expected Closeness or Mobilisation: Why Do Voters Go to the Polls? Empirical Results for Switzerland, 1981 - 1999, January 2005

1388 Emanuele Bacchiocchi and Alessandro Missale, Managing Debt Stability, January 2005

1389 Assar Lindbeck and Dirk Niepelt, Improving the SGP: Taxes and Delegation rather than Fines, January 2005

1390 James J. Heckman and Dimitriy V. Masterov, Skill Policies for Scotland, January 2005

1391 Emma Galli \& Fabio Padovano, Sustainability and Determinants of Italian Public Deficits before and after Maastricht, January 2005

1392 Angel de la Fuente and Juan Francisco Jimeno, The Private and Fiscal Returns to Schooling and the Effect of Public Policies on Private Incentives to Invest in Education: A General Framework and Some Results for the EU, January 2005

1393 Juan C. Conesa and Carlos Garriga, Optimal Response to a Demographic Shock, January 2005 
1394 Christian Gollier, Optimal Portfolio Management for Individual Pension Plans, February 2005

1395 Ruslan Lukach, Joseph Plasmans and Peter M. Kort, Innovation Strategies in a Competitive Dynamic Setting, February 2005

1396 Gebhard Kirchgässner, (Why) Are Economists Different?, February 2005

1397 Marko Köthenbürger, Panu Poutvaara and Paola Profeta, Why are More Redistributive Social Security Systems Smaller? A Median Voter Approach, February 2005

1398 Gabrielle Demange, Free Choice of Unfunded Systems: A First Assessment, February 2005

1399 Carlos Fonseca Marinheiro, Sustainability of Portuguese Fiscal Policy in Historical Perspective, February 2005

1400 Roel M. W. J. Beetsma and Koen Vermeylen, The Effect of Monetary Unification on Public Debt and its Real Return, February 2005

1401 Frank Asche, Petter Osmundsen and Maria Sandsmark, Is It All Oil?, February 2005

1402 Giacomo Corneo, Media Capture in a Democracy: The Role of Wealth Concentration, February 2005

1403 A. Lans Bovenberg and Thijs Knaap, Ageing, Funded Pensions and the Dutch Economy, February 2005

1404 Thiess Büttner, The Incentive Effect of Fiscal Equalization Transfers on Tax Policy, February 2005

1405 Luisa Fuster, Ayşe İmrohoroğlu and Selahattin İmrohoroğlu, Personal Security Accounts and Mandatory Annuitization in a Dynastic Framework, February 2005

1406 Peter Claeys, Policy Mix and Debt Sustainability: Evidence from Fiscal Policy Rules, February 2005

1407 James M. Malcomson, Supplier Discretion over Provision: Theory and an Application to Medical Care, February 2005

1408 Thorvaldur Gylfason, Interview with Assar Lindbeck, February 2005

1409 Christian Gollier, Some Aspects of the Economics of Catastrophe Risk Insurance, February 2005 